Original article

\title{
Relative effect of four characteristics that restrain the population growth of the mite Varroa destructor in honey bee (Apis mellifera) colonies
}

\author{
Miguel E. Arechavaleta-Velasco ${ }^{a *}$, Ernesto GuZmán-NovoA ${ }^{\mathrm{b}}$ \\ a Department of Entomology, Purdue University, West Lafayette, IN, 47907, USA \\ b CENIFMA-INIFAP, Santa Crúz \# 29-B, Las Hdas, Metepéc, Méx, Mexico
}

(Received 25 July 2000; revised 21 December 2000; accepted 6 February 2001)

\begin{abstract}
This study was conducted to determine the existence of phenotypic and genotypic variation in the ability of honey bee colonies to restrain the population growth of the mite Varroa destructor Anderson and Trueman, and to asses the relative effect of four characteristics that may confer tolerance to honey bees toward the mite. Fifty-eight colonies infested with an equal number of mites were sampled monthly during six months to determine their levels of infestation on adult bees and in worker brood. At the end of this period, 16 colonies were selected to study the effect of grooming behavior, hygienic behavior, brood attractiveness, and host-induced non-reproduction. The infestation-levels in adult bees varied significantly between colonies (range: 6.6-44.7\%), but no differences were found in the brood infestation levels. The variation between colonies was partially genetic in origin. Grooming behavior explained most of the variation $\left(r^{2}=0.38\right)$. Negative correlations were found between the mite population growth and both the total number of mites and the number of injured mites collected from the bottom-boards ( $r=-0.65$ and $r=-0.76$, respectively). Differences were found for hygienic behavior but the effect of this mechanism was not clear. No differences were found among colonies for brood attractiveness, or for the effect of the brood on the mite's reproduction.
\end{abstract}

Apis mellifera / Varroa destructor / tolerance / mechanisms of resistance / Mexico / grooming behavior / hygienic behavior

\section{INTRODUCTION}

The mite Varroa destructor Anderson and Trueman is the most serious threat that the beekeeping industry faces worldwide.
At present, infested colonies are treated with chemical products which give a certain degree of mite control. However in the long term, the use of miticides can cause a number of serious problems: (1) mite populations

* Correspondence and reprints

E-mail: miguel @ entm.purdue.edu 
are able to develop resistance to chemical products (Lodesani et al., 1995; Hillesheim et al., 1996; Elzen et al., 1999); (2) miticides can leave chemical residues in honey and wax (Faucon and Flamiini, 1990; Slabezki et al., 1991; Lodesani et al., 1992; Wallner, 1999); and (3) treatments with chemical miticides increase the cost of honey production.

The complete eradication of $V$. destructor is impossible. However, the beekeeping industry needs ways of maintaining productive colonies with low levels of infestation. Because of the serious disadvantages of chemical products, it is necessary to develop alternative methods of controlling the mite. One option is the development of Varroatolerant honey bee (Apis mellifera L.) strains. The development of genotypes that are able to maintain low levels of mite infestation would allow beekeepers to keep healthier and productive colonies and would decrease the risks and costs associated with the use of chemical miticides. This goal would be feasible if mechanisms of tolerance to the mite exist among honey bee populations, if there is variation for these mechanisms, and if these mechanisms are heritable (Guzmán-Novoa and Correa, 1996).

$V$. destructor is not a serious pest for Apis cerana Fabr., its original host. This honey bee species has developed mechanisms of tolerance, as a result of natural selection through a long association with the mite (Peng et al., 1987). In the case of A. mellifera, there are reports of colonies that survived in areas that were seriously damaged by $V$. destructor, which suggests the existence of a certain degree of tolerance in some genotypes of honey bees (Engels et al., 1986; Kulincevic and Rinderer, 1986; Kulincevic and Rinderer, 1988; Moosbeckhofer et al., 1988; Wallner, 1990; Morse et al., 1991). In Brazil it has been shown that the climate and the race of the bees (European or Africanized), has an influence on the colonies' degree of infestation. Warmer climates and
Africanized bees restrain the development of high levels of mite infestation (Moretto et al., 1991). Additionally, different $V$. destructor genotypes have been found to parasitize A. mellifera (De Guzman et al., 1997; Anderson, 2000). These genotypes may represent mite populations with different virulence, which could also explain why some populations of honey bees survive and maintain low levels of $V$. destructor infestations.

One defense mechanism against the mite in A cerana is grooming behavior. A worker bee is able to groom herself with her legs and mandibles to get rid of a mite. If she cannot get rid of it, she performs a dance to attract other workers that may help her to remove the mite from her body (Peng et al., 1987).

Grooming behavior has been measured with indirect methods in A. mellifera, but was observed at a lower frequency than in A. cerana (Morse et al., 1991; Ruttner and Hänel, 1992; Boecking et al., 1993; Rosenkranz et al., 1997; Bienefeld et al., 1999). There are reports of mites that apparently were injured by worker bees with their mandibles (Wallner, 1990; Morse et al., 1991; Moosbeckhofer, 1992; Ruttner and Hänel, 1992; Boecking et al., 1993; Moretto et al., 1993; Rosenkranz et al., 1997). In the study conducted by Moosbeckhofer (1992), a negative correlation between the number of injured mites and the total level of infestation in the colonies was found, suggesting that grooming behavior was responsible for lower levels of mite infestation. In the study by Moretto et al. (1993) it was found that Africanized bees eliminated more mites from their bodies than European bees and that the heritability of this behavior was 0.71 , which suggests that breeding for higher grooming behavior may be possible.

Worker bees of $A$. cerana also have the ability to detect capped brood that is infested by $V$. destructor; the bees open infested cells to remove mites. This behavior is known as hygienic or removal behavior (Peng et al., 
1987; Rath and Drescher, 1990; Boecking, 1992). Studies conducted by Boecking and Drescher (1991) showed that A. mellifera workers of the Carniolan race were able to detect, uncap, and remove pupae infested with $V$. destructor. Results of another study showed a negative correlation between the degree of hygienic behavior and the susceptibility to $V$. destructor of four honey bee lines (Büchler, 1992). In the United States, genetic programs to develop hygienic bee genotypes have been very successful (Rothenbuhler, 1964; Spivak, 1996; Spivak and Reuter, 1998). Colonies selected for hygienic behavior had lower mite levels than non-hygienic ones. However, researchers point out that further experiments are necessary to determine to what extent hygienic behavior reduces the mite load within a colony (Spivak, 1996; Spivak and Reuter, 1998; Boecking and Spivak, 1999).

The relative attractiveness of worker brood and adult bees to the mite may be another tolerance mechanism (Büchler, 1989). Guzmán-Novoa et al. (1996) found that the worker brood of Africanized bees was two times less attractive to $V$. destructor than the brood of European bees. Worker brood of hybrid bees (Africanized $\times$ European) was as attractive to the mite as brood of European bees. In the case of adult bees, European bees were more attractive to $V$. destructor than Africanized or hybrid workers.

Other mechanisms that may restrain the mite population growth include host factors that affect its reproduction. The percent of $V$. destructor females that reproduce on bee worker brood show variation depending on the species, race, and gender of the host. $V$. destructor does not reproduce successfully on the worker brood of A. cerana (Koeniger et al., 1981), and there are differences in the number of mites that reproduce on the brood of different races and commercial stocks of $A$. mellifera (Ritter and De Jong, 1984; Rosenkranz and Engels,
1994; Harbo and Hoopingarner, 1997; Harbo and Harris, 1999).

In spite of the fact that the above mechanisms of mite tolerance have been identified in different populations of honey bees, the relative contribution of each of them to the overall mite tolerance is not clear. To develop a breeding program to select honey bee genotypes that restrain the growth of the mite population, it is important to determine if there is genetic variation for this trait, and to determine the relative contribution of each of the mechanisms responsible for the tolerance. This information would facilitate the selection of honey bees based on the mechanisms that have a larger contribution to the mite tolerance.

The objectives of this study were (1) to determine if Mexican honey bees vary in their ability to restrain the growth of $V$. destructor population, (2) to decompose this variation into genotypic and environmental effects, and (3) to determine the relative contribution of four characteristics that are thought to confer tolerance to honey bees toward $V$. destructor.

\section{MATERIALS AND METHODS}

\subsection{Establishment of the experimental colonies}

The experiments were conducted in Valle de Bravo, State of Mexico (19 $14^{\prime} \mathrm{N}$; $100^{\circ} 06^{\prime} \mathrm{W}$ ), in the central region of Mexico. Fifty-eight colonies were established in jumbo-size hives in the same apiary. Each colony was established with four frames of brood and $2 \mathrm{~kg}$ of adult bees. A marked queen was randomly introduced into each colony. The queens were obtained from seven different breeders (lines) whom do not exchange breeding stock and are geographically isolated from each other.

Each colony was treated with two plastic strips impregnated with fluvalinate (Apistan ${ }^{\circledR}$, Novartis laboratories) for nine 
weeks to ensure that they were free of $V$. destructor, or that they had very low levels of infestation before the initiation of the experiments.

All the colonies were managed in the same way. The colonies were fed with $2 \mathrm{~L}$ of $50 \%$ sucrose syrup, and were treated with Terramycin $^{\circledR}$ (Pfizer laboratories) every 15 days until the beginning of the honey flow, to provide them with enough food to permit their development, and to prevent a foulbrood outbreak.

\subsection{Variation in the ability of honey bee colonies to restrain the growth of $V$. destructor population}

Two weeks after the Apistan ${ }^{\circledR}$ strips were removed from the colonies, each of them was artificially infested with 25 mites. Twenty-five workers of each colony were confined in two Benton queen cages and one adult female of $V$. destructor was placed on the body of each worker with a fine brush (Krause and Page, 1995). The cages with the infested workers were re-introduced into their respective colony, so that the infested bees could be released by the workers of their colony.

The mites used to infest the experimental colonies came from one highly infested colony located $8 \mathrm{~km}$ away from the experimental apiary. To collect the mites, a $19 \mathrm{~L}$ plastic container which had a $4 \mathrm{~mm}$ wiremesh screen $20 \mathrm{~cm}$ above its bottom was used. Between the bottom of the container and the screen, two $40 \mathrm{ml}$ vials half-filled with ether were placed. Workers of the infested colony were shaken into the container that was then closed for $5 \mathrm{~min}$ to anaesthetize the bees and to allow the mites to fall off of the workers. Then the mites were collected from the bottom of the container.

The number of frames containing brood and that were covered with adult bees were counted in each of the experimental colonies every month, during six months, to determine if there were differences in population among the colonies.

To evaluate the relative mite tolerance of the experimental colonies, the growth of the mite population was recorded by taking monthly samples of workers and brood from the colonies for a period of six months. The first samples were taken two months after the colonies were initially infested.

Three segments of comb each with at least 50 capped cells of worker brood were collected from the three central frames of each colony and were kept at $-5{ }^{\circ} \mathrm{C}$ until they were examined. Each cell was uncapped in search for mites, and the level of infestation of the brood was determined by dividing the number of cells infested by the total number of cells in the sample and multiplying the resulting figure by 100 .

The level of infestation of adult bees was determined by collecting and examining four samples of 100 workers from each colony (400 workers per colony). The samples were taken from the four central frames of each hive, collecting the bees in jars that were previously filled with $70 \%$ ethanol. Following the technique described by De Jong et al. (1982), the number of mites detected in each sample was divided by the number of bees in the sample, and the resulting figure was multiplied by 100 .

Data were transformed by the Box and Cox method to provide a normal distribution (Snedecor and Cochran, 1991), and were subjected to an analysis of variance under a complete random design to determine differences in the levels of infestation among colonies, as evidence of phenotypic variation in their ability to restrain the growth of $V$. destructor population.

To identify genotypic effects, the data were subjected to an analysis of variance under an unbalanced nested design with repeated observations. The model was:

$$
\mathrm{Y}_{\mathrm{ijkl}}=\mu+\mathrm{L}_{\mathrm{i}}+\mathrm{Q}_{\mathrm{j}(\mathrm{i})}+\mathrm{S}_{\mathrm{k}}+\mathrm{E}_{\mathrm{ijkl}}
$$


where

$\mathrm{Y}_{\mathrm{ijkl}}=$ level of infestation

$\mu=$ population mean

$\mathrm{L}_{\mathrm{i}} \quad=$ line $^{*}$ effect $(\mathrm{i}=1,2, \ldots, 7)$

$\mathrm{Q}_{\mathrm{j}(\mathrm{i})}=$ colony (queen) effect nested into the line $\left(\mathrm{j}=1,2, \ldots \mathrm{n}_{\mathrm{j}}\right)$

$\mathrm{S}_{\mathrm{k}}=$ sample time effect $(\mathrm{k}=1,2, \ldots, 5)$

$\mathrm{E}_{\mathrm{ijkl}}=$ random error.

The components of the variance were estimated by using the restricted maximum likelihood (REML) (Van Vleck, 1993; Lynch and Walsh, 1998), counting the effect of the lines and the effect of the colony (queen) nested into the line, under the next model:

where

$$
\mathrm{Y}_{\mathrm{ijk}}=\mu+\mathrm{L}_{\mathrm{i}}+\mathrm{Q}_{\mathrm{j}(\mathrm{i})}+\mathrm{E}_{\mathrm{ijk}}
$$

$\mathrm{Y}_{\mathrm{ijk}}=$ level of infestation

$\mu=$ population mean

$\mathrm{L}_{\mathrm{i}} \quad=$ line $^{*}$ effect $(\mathrm{i}=1,2, \ldots, 7)$

$\mathrm{Q}_{\mathrm{j}(\mathrm{i})}=$ colony (queen) effect nested into the line $\left(j=1,2, \ldots, n_{j}\right)$

$\mathrm{E}_{\mathrm{ijkl}}=$ random error.

The genotypic variance was estimated from the variation of the line effect and from the colony (queen) effect nested into the line. The environmental variance was estimated by the variance of the error (Falconer, 1989; Van Vleck, 1993; Lynch and Walsh, 1998).

\subsection{Relative contribution of four characteristics to the variation in the growth of $V$. destructor population}

To estimate the relative effect of four presumed mechanisms of mite tolerance, the 16 colonies with the most extreme levels of mite infestation after six months of monitoring, were selected; the eight colonies with the lowest levels, and the eight with the highest. The colonies were selected on the basis of their infestation of adult bees, since no differences in the brood infestation levels were found among colonies (see results). The remaining colonies were treated with Apistan ${ }^{\circledR}$ strips.

\subsubsection{Grooming behavior}

To analyze the effect of the bees' grooming behavior, experiments were conducted in both the selected colonies and in an incubator. Screen ( $4 \mathrm{~mm}$ wire-mesh) bottom boards were placed in each colony. To collect the mites that fell from a colony, each bottom board was assembled with a sheet of white paper smeared with vegetable shortening beneath the wire-mesh screen. Each week during five weeks, the paper sheets were collected and replaced with new ones. The mites that were stuck on the old sheets were counted and transferred with a fine brush into a jar containing $70 \%$ ethanol. A random sample of 120 mites per colony was taken from all the mites that were recovered. Then, the number of injured mites in the sample was recorded with the aid of a stereoscopic microscope. The injuries observed in the mites were similar to those described by several authors (Wallner, 1990; Moosbeckhofer, 1992; Ruttner and Hänel, 1992; Moretto et al., 1993). Only the injuries of indentations in the idiosoma of the mites were considered. Injuries in the legs were not considered because many of them may have been caused by the manipulation of the samples.

To perform the incubator assay, 30 workers were collected from each of the selected colonies, and were introduced into a $4 \mathrm{~mm}$ wire-mesh cage $(10 \times 10 \times 20 \mathrm{~cm})$. A piece

\footnotetext{
* In the two previous models each queen source (breeder) was considered a line, assuming the existence of different allelic and genotypic frequencies for each of the lines. These considerations were based on the fact that the breeders do not exchange breeding stock, that the honey bee populations from each breeder are geographically isolated from each other, and that each population has been exposed to natural and artificial selection in their particular environments.
} 
of white paper smeared with vegetable shortening and covered with a $4 \mathrm{~mm}$ wire-mesh, was placed at the bottom of each cage. The workers of each cage were artificially infested with 10 mites with a fine brush. Then, the cages were placed and kept in an incubator $\left(30{ }^{\circ} \mathrm{C}, 55 \% \mathrm{RH}\right)$. Bees were offered water ad libitum, and a paste made of a mixture of honey and powdered sugar. The bees were kept in the incubator for $48 \mathrm{~h}$ and the number of falling mites was counted every $12 \mathrm{~h}$. At the end of this period, the number and proportion of mites with injuries in the idiosoma was determined.

\subsubsection{Hygienic behavior}

The bees' hygienic behavior was measured using a modification of the test described by Newton and Ostasiewski (1986). Three frames containing capped brood were chosen from each of the selected colonies. On each frame, three groups of seven cells were punctured with a fine pin to kill the brood. The frames were re-introduced in the middle of their hive and were inspected $24 \mathrm{~h}$ later to count the number of cells that had been cleaned by the bees.

\subsubsection{Brood attractiveness and its effect on $\mathrm{V}$. destructor reproduction}

Brood attractiveness and its effect on the $V$. destructor reproductive capability were measured using a modification of the technique described by Guzmán-Novoa et al. (1996). Each queen of the selected colonies was confined on a frame that was placed inside a screen cage in its respective colony. The screen of the cages permitted workers to pass and take care of the queens, but did not permit the queens to leave the cages. Queens laid eggs on these combs within $24 \mathrm{~h}$ after being caged. Four days after the queens were caged, the combs were removed from the colonies and a square section (approx. $20 \mathrm{~cm}^{2}$ ) containing young larvae was cut out from each comb. Then, the sections were installed in a jumbo-size frame, alternating one segment from a low infested colony with a segment from a high infested colony, to minimize any effect due to their position in the frame.

The frame containing the comb segments was introduced in the center of a colony that was highly infested with $V$. destructor. The infested colony was prepared in advance to receive the frame. Combs containing open brood cells were removed from the hive to increase the chances that $V$. destructor mites would infest the experimental brood. The queen of this colony was confined in a Benton cage to prevent her from laying on the experimental comb sections.

Fourteen days after being introduced, the experimental frame was removed from the colony, and the comb sections were placed in individual plastic bags and kept at $-5.0^{\circ} \mathrm{C}$ until analyzed. Cells of each comb section were uncapped and examined. The number of cells containing mites was recorded to infer brood attractiveness, whereas the number of mature and immature mites found in each cell were recorded to determine the effect of the brood on the mite's reproductive capability.

The data obtained from each of the assays were tested for normality, and the means of each characteristic measured in the eight colonies with low infestations were compared with those of the eight colonies with high infestations, using a $t$-test. In addition, the data of the selected colonies were subjected to an analysis of variance under a complete random design, to identify differences among the selected colonies for the characteristics under study.

Finally, for characteristics that showed significant differences between groups or colonies, analysis of regression and correlation were performed between the final levels of infestation of the colonies, and their values for each trait measured.

The magnitude of the $t$ statistic, the value of the determination coefficient from the analysis of regression, and the correlation 
coefficient, were used to determine the relative contribution of the characteristics to the ability of the honey bee colonies to restrain the growth of the mite population.

\section{RESULTS}

\subsection{Variation in the ability of honey bee colonies to restrain the growth of $V$. destructor population}

\subsubsection{Phenotypic variation}

Significant differences were found among colonies for the levels of infestation of adult bees after a period of six months $(F=1.57$; $d f=57,205 ; P<0.01)$, but no differences were found for the levels of infestation of the brood for the same period of time
$(F=0.71 ; d f=57,177 ; P>0.05)$. The final levels of infestation of the adult bees ranged from 6.6 to $44.7 \%$ and the final levels of infestation of the brood range from 25.5 to $60.4 \%$.

\subsubsection{Genotypic and environmental variation}

The levels of infestation on adult bees grew significantly month to month from the beginning of the experiment $(F=91.26$; $d f=4,201 ; P<0.001)$. There were significant differences among lines $(F=5.32$; $d f=6,201 ; P<0.001)$ and among colonies nested into lines $(F=3.06 ; d f=51,201$; $P<0.001)$ for the levels of infestation (Fig. 1).

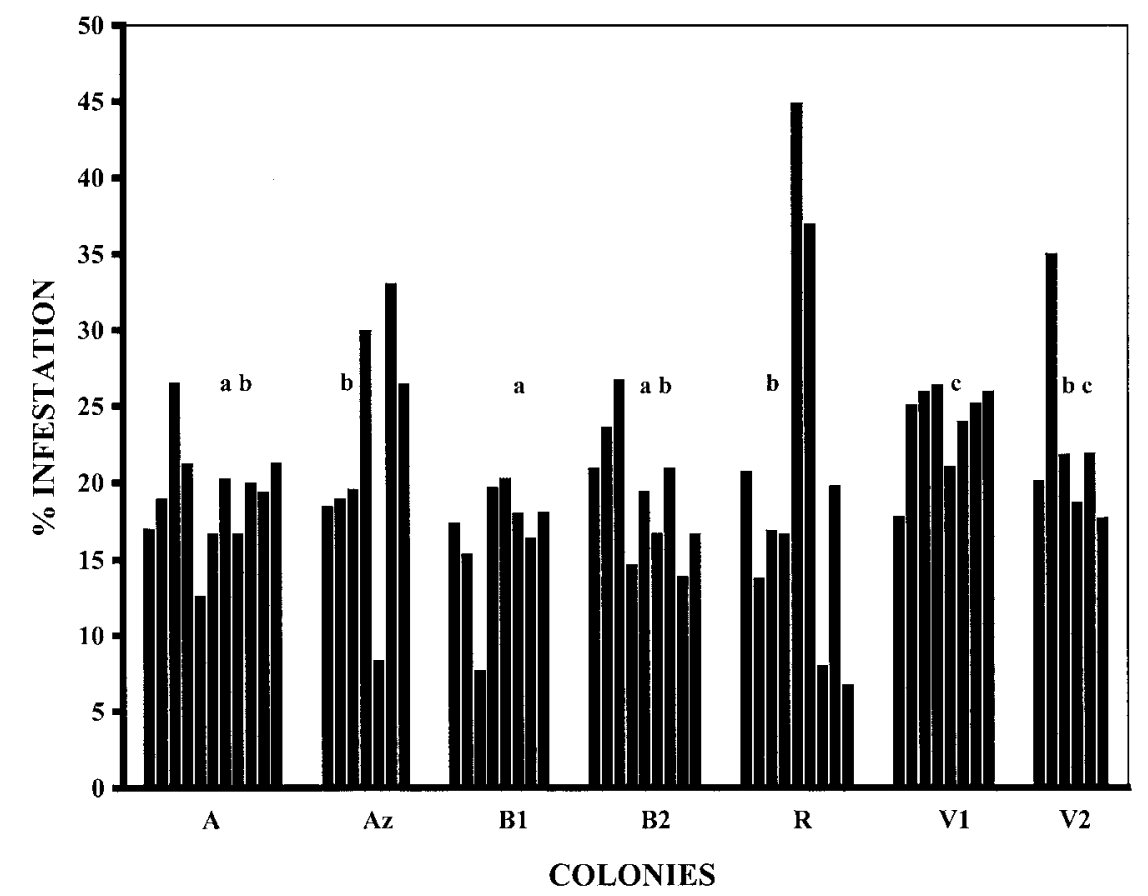

Figure 1. Levels of Varroa destructor Anderson and Trueman infestation of adult bees of colonies from seven different lines (A, Az, B1, B2, R, V1, and V2) after six months of infestation. There were significant differences among colonies nested into the lines $(F=3.06 ; d f=52,201 ; P<0.001)$ and among lines $(F=5.32 ; d f=6,201 ; P<0.001)$. Different letters indicate differences between the means of the lines, based on ANOVA and LSM tests. Statistical tests (ANOVA and LSM) were performed with transformed data using the Box and Cox function. The values in the figure represent actual non-transformed data $(n=58)$. 
The components of the analysis of variance showed that part of the variation was related to the line effect, and part was related to the colonies nested into lines. The variation due to the colonies was higher than the variation due to the lines. The variation related to the line effect and to the colony effect are components of the genotypic variance. The variation related to the error in the model is an estimator of the environmental variance (Tab. I).

The infestation levels of the brood increased significantly month to month over the sampling period $(F=98.49 ; d f=4,173$; $P<0.001)$. However, no differences were found among lines $(F=1.95 ; d f=6,173$; $P>0.05)$, and colonies nested into lines $(F=1.34 ; d f=51,173 ; P>0.05)$ for this trait.

\subsection{Relative contribution of four characteristics to the variation in the growth of $V$. destructor population}

The infestation levels of the brood and adult bees increased in the 16 selected colonies over the six months period after being artificially infested. However, the rate of increase was higher in the high infested than in the low infested group (Figs. 2, 3). After the last sampling, the mean levels of infestation of adult bees were 10.5 for the low infested colonies, and $32.3 \%$ for the high infested colonies. These levels differed significantly $(t=8.48 ; d f=14 ; P<0.001)$. The mean levels of infestation of the brood were 39.8 and $43.4 \%$ for the low, and for the high infested groups, respectively. These levels were not different $(t=0.48 ; d f=14$; $P>0.05)$. Moreover, the bee population measured as number of combs covered with adult bees, and as number of combs containing brood, did not differ among the selected colonies $(U=73.5 ; U=71.0$ for combs with bees and for combs with brood, respectively; $P>0.05$; Mann-Whitney $U$ test).

\subsubsection{Grooming behavior}

Significantly more mites were collected from the low-infested than from the highinfested colonies $(t=2.41 ; d f=14 ; P<0.05$; Tab. II). The mean number of mites collected per week were 186.3 and 386.3 for the high and for the low infested groups, respectively. There were significant differences among colonies for the number of mites collected per week $(F=6.47 ; d f=15$, 60; $P<0.001)$.

Table I. Variance sources for the ability of honey bee colonies to restrain the population growth of Varroa destructor Anderson and Trueman estimated by restricted maximum likelihood (REML).

\begin{tabular}{lc}
\hline Variance sources & Estimator \\
\hline Lines & 0.0129 \\
Colonies nested into lines & 0.0578 \\
Error & 0.1228 \\
Total & 0.1935 \\
\hline
\end{tabular}

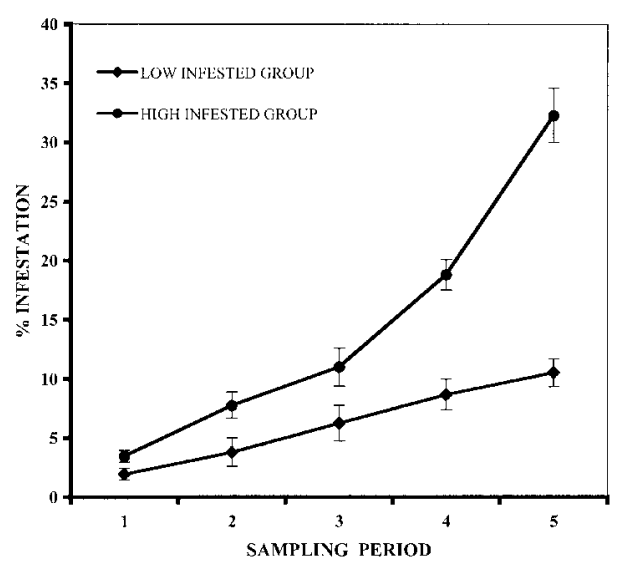

Figure 2. Average levels ( $\pm \mathrm{SE}$ ) of Varroa destructor Anderson and Trueman infestation of adult bees from two groups of colonies selected for their high $(n=8)$ and low $(n=8)$ ability to restrain the mite population growth for five monthly sampling periods. 
A significant negative correlation was found between the number of mites collected from the bottom boards and the final infestation levels of the colonies $(r=-0.65 ; n=16 ; P<0.01)$. A linear regression analysis between these two variables showed a significant relationship, explaining $38 \%$ of the variation $\left(r^{2}=0.38\right.$; $n=16 ; P<0.01$; Tab. III; Fig. 4).

Regarding the number of injured mites, significant differences were found between the means of the two groups $(t=2.61$; $d f=14 ; P<0.05$; Tab. II). The high infested

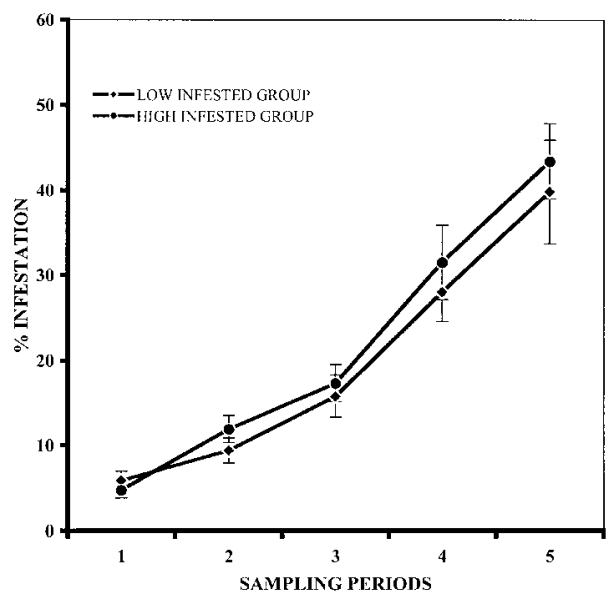

Figure 3. Average levels $( \pm \mathrm{SE})$ of Varroa destructor Anderson and Trueman infestation of the brood from two groups of colonies selected for their high $(n=8)$ and low $(n=8)$ ability to restrain the mite population growth for five monthly sampling periods. group had a mean of 11.3 mites with injuries in their idiosoma, which represented $9.4 \%$ of the total number of mites sampled, whereas the mean of the low infested group was 13.5 injured mites, which represented $11.3 \%$ of the mites sampled. A negative correlation was found between the number of injured mites and the final infestation levels of the colonies $(r=-0.76 ; n=16 ; P<0.001)$. A linear regression analysis between these two

Table II. Differences for presumed mechanisms of tolerance between two groups of colonies selected for their Varroa destructor Anderson and Trueman infestation level (high and low). Figures in parentheses are d.f.

\begin{tabular}{lcc}
\hline Mechanism & $t$ & $P$ \\
\hline Grooming behavior & 2.41 & 0.03 \\
No. fell mites from hive tests & $(14)$ & \\
Grooming behavior & 2.61 & 0.02 \\
No. injured mites from hive tests & $(14)$ & \\
Grooming behavior & 2.20 & 0.04 \\
No. mites from incubator tests & $(14)$ & \\
Grooming behavior & 0.92 & 0.79 \\
No. injured mites from incubator tests & $(14)$ & \\
Hygienic behavior & -0.64 & 0.53 \\
No. cleaned cells & $(14)$ & \\
Brood attractiveness & -0.11 & 0.91 \\
Proportion infested cells & $(14)$ & \\
Varroa reproduction & 0.49 & 0.62 \\
Proportion of mites that reproduced & $(14)$ &
\end{tabular}

Table III. Correlation $(r)$ and determination $\left(r^{2}\right)$ coefficients between the final Varroa destructor Anderson and Trueman level of infestation of the selected colonies and the number of mites recovered and injured from the assays used to measure grooming behavior in the hives and in an incubator.

\begin{tabular}{lcccl}
\hline Characteristic & $n$ & $r$ & $r^{2}$ & $P$ \\
\hline Recovered mites (Hive) & 16 & -0.65 & 0.38 & 0.008 \\
Injured mites (Hive) & 16 & -0.76 & 0.54 & 0.0001 \\
Recovered mites (Incubator) & 16 & -0.52 & 0.22 & 0.04 \\
Injured mites (Incubator) & 16 & -0.23 & 0.06 & 0.45 \\
\hline
\end{tabular}


variables showed a significant relationship, explaining $54 \%$ of the variation $\left(r^{2}=0.54\right.$; $n=16 ; P<0.001$; Tab. III; Fig. 5).

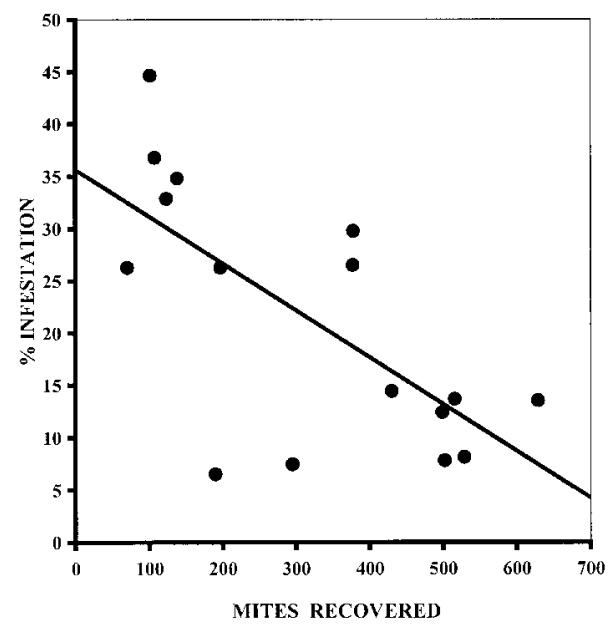

Figure 4. Relationship between the colonies' final levels of infestation and the mean number of mites recovered per week from the selected colonies. The regression equation is $\mathrm{Y}=35.35$ $0.043 \mathrm{X}\left(r^{2}=0.38 ; P=0.008 ; n=16\right)$.

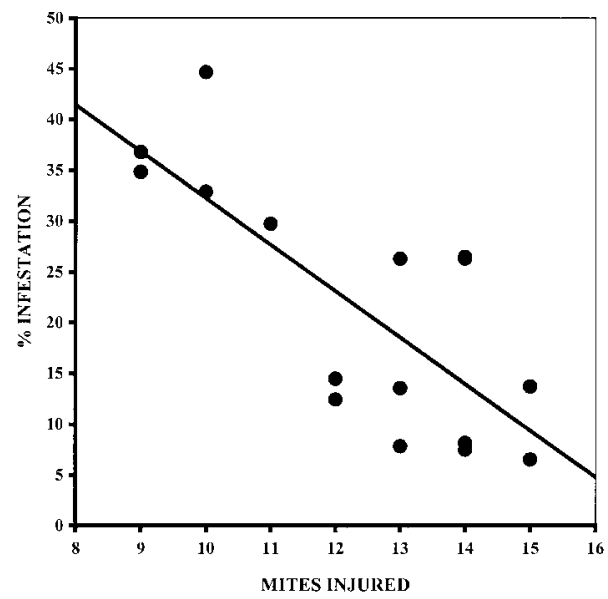

Figure 5. Relationship between the colonies' final levels of infestation and the number of injured mites found in a random sample ( $n=120)$ recovered from the hives' bottom boards of the selected colonies. The regression equation is $\mathrm{Y}=78.105-4.582 \mathrm{X}\left(r^{2}=0.54\right.$; $P=0.0001 ; n=16)$.
Significant differences were found between the means of the two groups for the number of mites recovered from the incubator cages $(t=2.20 ; d f=14 ; P<0.05)$. The mean of the high infested group was 2.3 mites, and the mean of the low infested group was 4.6 mites (Tab. II).

A negative correlation was found between the number of mites recovered in the incubator tests and the final levels of infestation $(r=-0.52 ; n=16 ; P<0.05)$. A linear regression analysis between these two variables showed a significant relationship, explaining $22 \%$ of the variation $\left(r^{2}=0.22\right.$; $n=16 ; P<0.05$; Tab. III).

No differences were found between the two groups for the number of injured mites in the incubator $(t=0.92 ; d f=14 ; P>0.05$; Tab. II), and no correlation was found between this variable and the final infestation levels of the colonies $(r=-0.23 ; n=16$; $P>0.05$; Tab. III).

\subsubsection{Hygienic behavior}

No differences were found between the two groups of colonies for the number of cells cleaned by the bees $(t=-0.637$; $d f=14 ; P>0.05$; Tab. II). The colonies of the high infested group had a mean of 54.8 cells cleaned $(87.0 \%)$, whereas the low infested group had a mean of 51.3 cells cleaned $(81.4 \%)$. However, an analysis of variance showed significant differences among colonies $(F=10.71 ; d f=15,116$; $P<0.001$ ), with a range from 11 to 63 cells cleaned (17.5-100.0\%). No correlation was found between the final levels of infestation of the colonies and the number of cells cleaned by the bees $(r=0.18 ; n=16$; $P>0.05)$.

\subsubsection{Brood attractiveness}

No differences were found between the two groups of colonies for the percentage of cells that were infested with mites $(t=0.11 ; d f=14 ; P>0.05 ;$ Tab. II $)$. The mean of the high infested group was $6.0 \%$ 
whereas that of the low infested group was $5.8 \%$. Also no differences were found among colonies for this trait $(F=0.02$; $d f=15,84 ; P>0.05)$.

\subsubsection{Brood effect on V. destructor reproduction}

No differences were found between the two groups of colonies for the percentage of infested cells in which the mites were able to reproduce $(t=0.495 ; d f=14$; $P>0.05$; Tab. II). The mites did not reproduce in $21.0 \%$ of the infested cells in the colonies of the high infested group, whereas in the colonies of the low infested group, mites did not reproduce in $28.5 \%$ of the infested cells. Additionally, no differences were found among colonies for this variable $(F=0.18 ; d f=15,84 ; P>0.05)$.

\section{DISCUSSION}

Our results showed high phenotypic and genotypic variation among colonies for the levels of infestation of $V$. destructor on adult bees, but no significant variation was found for the levels of infestation in the brood. These results apparently suggest that the ability of the colonies to restrain the $V$. destructor population growth found in this study was related to the colonies capacity to control the mite population when they were phoretic on adult bees. The lack of significant variation in the infestation levels in the brood could have resulted from the lack of differences between groups for hygienic behavior, brood attractiveness to the mite, and brood effect on the mite reproduction, which are mechanisms that affect the mite population growth at the brood stage of the bee's life.

The variation in the mite population growth of the experimental colonies agrees with results reported by several authors (Engels et al., 1986; Kulincevic and Rinderer, 1988; Kulincevic et al., 1988; Moosbeckhofer et al., 1988; Moretto et al.,
1991; Harbo and Hoopingarner, 1997). Additionally, the fact that part of the variation was explained by genotypic effects is in agreement with results reported by Ron and Rosenthal (1987), whom showed that part of the variation in the $V$. destructor infestation levels of their experimental colonies was due to differences in the genetic origin of the lines of honey bees that they used.

It is important to notice that the largest part of the genotypic variation was found among the colonies, and not among the lines, which suggest that it is possible to find tolerant stocks within the different populations of honey bees that queen breeders keep, and that this characteristic is not related to a particular line.

Results of this study suggest that the variation in the growth of $V$. destructor population found in the experimental colonies could be explained mainly by the workers' ability to eliminate mites infesting adult bees, presumably by grooming behavior, since this was the only characteristic measured that showed significant differences between groups and among colonies. The number of mites recovered from the low infested colonies in both the incubator and the hives was significantly higher than the number of mites recovered from the high infested colonies. Moreover, the low infested colonies had more injured mites, and significant negative correlations were found between the final levels of infestation of the colonies and both the number of recovered and injured mites. The fact that no differences were found between the groups for the number of injured mites in the incubator tests may have been a consequence of a small sample size, or it may be that other mechanisms in addition to grooming behavior were also responsible for the differences obtained in the field tests.

It has been shown that there is a positive correlation between mite infestation levels in colonies and mite drop on bottom boards (Fries et al., 1991; Calatayud and Verdu, 1993). Our results are not in agreement with 
these findings, since more mites were recovered from the bottom boards of the colonies belonging to the low infested group than from those of the colonies of the high infested group. Results of our study support those of Moosbeckhofer (1992), who also found a negative correlation between the number of injured mites and the $V$. destructor infestation levels of the colonies of his study. Our findings could be due to the fact that we selected colonies with extreme levels of infestation as a result of their differential ability to restrain the mite population growth. Thus, our colony groups were not average colonies, but colonies with differences in susceptibility to mite infestation on adult bees. Differences in the susceptibility of adult bees to become infested with $V$. destructor mites have been found between European and Africanized bee colonies. Africanized and hybrid bees were two times less susceptible to become infested than European workers (GuzmánNovoa et al., 1996). In another study, Moretto and Mello (2000) measured $V$. destructor mortality rates by recovering mites from bottom board trays installed in Africanized colonies. They found that the colonies with the highest $V$. destructor mortality rates had the lowest levels of infestation on adult bees $(r=-0.83)$. The above studies support our findings, and suggest that the bees of some colonies eliminate more mites than the bees of others.

An alternative hypothesis to explain why we found more falling mites in the low infested than in the high infested colonies is that there may have been differences in the amount of brood and bees between our groups of colonies. Positive correlations between number of mites on bottom boards with amount and emergence of brood have been reported (Lobb and Martin, 1997; Beetsma et al., 1999). However, there were no differences in the number of combs with bees and with brood between our two groups of colonies. Therefore, it seems that the workers of colonies from the low infested group had a higher grooming ability than the workers of colonies from the high infested group. It could also be that a combined effect of grooming and hygienic behavior was responsible for the differences between our two groups of colonies. Damaged mites found on bottom boards can not be attributed exclusively to the grooming behavior of worker bees. Hygienic bees and wax moths may cause damage to mites seen on bottom boards too (Szabo and Walker, 1995; Boecking and Spivak, 1999). Thus, the methods that we used could not asses and separate what proportion of mites fell and what proportion of mites were injured as a result of the bees' grooming behavior, hygienic behavior, or other causes. However, it was clear that adult bees from the two groups differed significantly in their levels of mite infestation, but did not differ in their levels of brood infestation. Therefore, it is likely that mechanisms associated with adult bees were responsible for the differences in the degree of infestation of our two groups of colonies.

The results reported here, as well as those from studies conducted in other countries (Morse et al., 1991; Moosbeckhofer, 1992; Ruttner and Hänel, 1992; Boecking et al., 1993; Moretto et al., 1993; Rosenkranz et al., 1997; Bienefeld et al., 1999), suggest that grooming behavior may be an important mechanism conferring tolerance to honey bee colonies toward $V$. destructor. However, the effects of grooming behavior must be interpreted with caution, because the reliability of the indirect methods used to quantify this behavior is controversial (Rosenkranz et al., 1997; Bienefeld et al., 1999; Boecking and Spivak, 1999).

The importance of hygienic behavior on conferring tolerance to honey bees to $V$. destructor is not clear. In the present study, the differences found among the colonies suggest that this mechanism could contribute to the bees' tolerance, but its effect was apparently smaller than that of grooming behavior, since no differences were found between the two groups of experimental colonies. The pin-killed 
method that we used to determine hygienic behavior might be questioned because its reliability has not been tested, and perhaps we were not able to accurately measure the actual hygienic ability of the experimental colonies. In other studies, Boecking and Drescher (1991) and Büchler (1992), reported that Carniolan bees that showed high hygienic behavior, also showed low levels of mite infestation. Spivak (1996) found that for two lines of honey bees, one hygienic and one non-hygienic, there were significant differences in the bees' ability to detect and remove pupae from cells that were previously infested with $V$. destructor mites in her first period of tests. But for a second period of tests, no differences were found between the two groups of colonies. Bär and Rosenkranz (1992) concluded that hygienic behavior does not confer significant resistance to the colonies against the mite.

No differences were found for the brood attractiveness to $V$. destructor between groups or among colonies. These results agree with those reported by Camazine (1986), who did not find differences between Africanized and European bees for the mite's preference for a particular type of brood. However these results differ from those of Guzmán-Novoa et al. (1996) whom found differences among colonies of European, Africanized, and hybrid genotypes. Additionally, no differences between colonies or between groups were found for the brood effect on the reproductive capability of the mite, which again suggests that this mechanism did not have a significant contribution on restraining the growth of the mite population in the experimental colonies of this study. These results also differ from those reported by several authors (Rosenkranz and Engels, 1994; GuzmánNovoa et al., 1996; Harbo and Hoopingarner, 1997), whom reported differences in the reproductive capability of the mite as a result of the effect of the infested brood's genotype.
The fact that no significant differences were found for the above two mechanisms in this study could be a consequence of a relatively small sample size. However, if their relative contribution had been high, differences should have been found even with the sample size that was used in the experiments. The honey bee colonies used in this study were obtained from commercial queen breeders, and thus, the experimental colonies were not highly Africanized, which could be another reason for the lack of agreement with the above studies.

Tolerance toward $V$. destructor has been documented in South America and Mexico, but the degree of tolerance and the mechanisms involved in this tolerance vary in different places (Guzmán-Novoa et al., 1999; Rosenkranz, 1999). Studies conducted in the Americas have shown that the factors which contribute to mite tolerance in honey bees are not the same in all bee populations. The low fertility of the mite is the main tolerance factor in honey bees in Brazil. However in other countries, characteristics such as lower attractivity of the bee brood, increased grooming, and hygienic behavior, have shown to be associated with low infestation levels of $V$. destructor in honey bee colonies (Moretto et al., 1993; GuzmánNovoa et al., 1996; Vandame et al., 1997; Guerra et al., 2000). Thus, it may be that some characteristics that have a strong influence on conferring tolerance toward the mite in some bee populations may not have a high influence in others.

It is critical to determine which and to what extent different characteristics and mechanisms confer tolerance to honey bee colonies toward $V$. destructor to facilitate the development of successful breeding programs for mite tolerant honey bees. However to accomplish this goal, studies are needed to develop direct and reliable techniques for measuring presumed tolerance characteristics. It is also important to take into account that tolerance to $V$. destructor in honey bees is influenced by multiple 
factors of the host, by differences in the mite's virulence, and by different environmental conditions, which could result in different levels of tolerance in bee colonies. Therefore, additional studies are necessary to confirm the actual contribution and importance of different bee characteristics in different environments, with different populations of honey bees, and with different strains of $V$. destructor mites.

\section{ACKNOWLEDGEMENTS}

This work was funded with grants from CONACYT and from the National Autonomous University of Mexico (UNAM). We thank Greg J. Hunt for critical review of this manuscript. We are grateful to Ruben Mendoza, Enrique Coronado, Gabriela Ortiz, Modesto Bautista, Enrique Estrada, Alberto Barrera, Salvador Cajero, and Antonio Zozaya whom provided assistance in various ways.

Résumé - Influence relative de quatre caractéristiques qui limitent la croissance de la population de l'acarien Varroa destructor dans les colonies d'abeilles domestiques (Apis mellifera). L'acarien Varroa destructor Anderson et Trueman représente la menace la plus grave pour l'industrie apicole mondiale. Actuellement les colonies infestées sont traitées avec des produits chimiques qui permettent dans une certaine mesure de contrôler le parasite. Pourtant sur le long terme, les acaricides peuvent être à l'origine d'un certain nombre de problèmes. Une solution pour lutter contre $V$. destructor est de développer des lignées d'abeilles tolérantes à l'acarien. L'étude a été faite pour déterminer s'il existe une variation phénotypique et génotypique de l'aptitude des colonies d'abeilles à limiter la croissance de la population de $V$. destructor et pour établir l'influence relative de quatre caractéristiques supposées conférer aux abeilles une tolérance à l'acarien. Cinquante huit colonies ont été installées dans des ruches de taille jumbo. Les reines à la tête de ces colonies provenaient de sept lignées différentes fournies par des sélectionneurs. Les colonies ont été infestées artificiellement avec 25 acariens. Pour évaluer la tolérance des colonies expérimentales vis-à-vis de l'acarien, on a enregistré la croissance de la colonie en prélevant chaque mois des échantillons d'ouvrières et de couvain pendant une période de six mois. Les données ont subi une analyse de variance afin de déterminer la variation phénotypique et génotypique. Les composantes de la variance ont été également estimées. Pour déterminer l'influence relative des quatre mécanismes de tolérance, on a choisi 16 colonies : les huit colonies ayant le taux d'infestation le plus bas et les huit qui avaient le taux d'infestation le plus élevé. On a étudié les mécanismes suivants : comportement de toilettage, comportement hygiénique, attractivité du couvain et non reproduction induite par l'hôte. Dans les colonies sélectionnées, chaque mécanisme a été mesuré à l'aide d'un test biologique. La valeur moyenne des 8 colonies les moins infestées a été comparée avec celle des huit les plus infestées à l'aide d'un test $t$. Les données ont subi en outre une analyse de variance pour identifier les différences entre colonies sélectionnées. Pour les mécanismes qui ont montré des différences significatives entre groupes ou entre colonies, on a réalisé une analyse de régression et une analyse de corrélation entre le niveau final d'infestation des colonies et les valeurs moyennes de chaque mécanisme mesuré. Une variation phénotypique a été trouvée entre les colonies pour les niveaux d'infestation des abeilles adultes, mais pas pour l'infestation du couvain (Figs. 2, 3). On a trouvé des différences significatives entre lignées et entre colonies au sein des lignées (Fig. 1), ce qui prouve une influence du génotype et du milieu (Tab. I). Concernant les mécanismes étudiés, des différences significatives ont été trouvées entre groupes et entre colonies pour le comportement de toilettage. Des corrélations significativement négatives ont été trouvées entre le niveau final d'infestation et le nombre 
d'acariens récupérés d'une part (Tab. II ; Fig. 4) et le nombre d'acariens blessés d'autre part (Tab. III ; Fig. 5). Pour le comportement hygiénique, des différences ont été trouvées entre colonies, mais pas entre groupes. Par contre aucune différence n'a été trouvée ni entre groupes ni entre colonies pour l'attractivité du couvain et pour l'effet du couvain sur la reproduction de l'acarien. Ces résultats suggèrent que, dans cette étude, la tolérance des colonies vis-à-vis de $V$. destructor était liée à l'aptitude des abeilles à limiter la population d'acariens lorsqu'ils sont dans la phase phorétique sur les abeilles adultes, vraisemblablement par le comportement de toilettage. Les problèmes et les implications liées aux méthodes utilisées pour mesurer les caractéristiques de tolérance, ainsi que les recherches à venir, sont discutées.

Apis mellifera / Varroa destructor / tolérance / mécanisme de résistance / comportement toilettage / comportement hygiénique / Mexique

Zusammenfassung - Der relative Einfluss von vier das Populationswachstum der Milbe Varroa destructor in Honigbienenvölkern (Apis mellifera) begrenzenden Eigenschaften. Die Milbe Varroa destructor Anderson und Trueman ist weltweit die ernsthafteste Bedrohung der Bienenindustrie. Gegenwärtig wird der Befall der Völker mit chemischen Behandlungsmitteln bis zu einem gewissen Grad unter Kontrolle gehalten. Langfristig verursachen Mitizide allerdings eine Reihe von Problemen. Eine Möglichkeit zur Bekämpfung der Milben ist die Entwicklung von gegenüber $V$. destructor toleranten Bienenlinien. Diese Untersuchung sollte die Existenz phenotypischer und genetischer Variation der Fähigkeit von Bienenvölkern belegen, das Populationswachstum von $V$. destructor zu begrenzen und weiterhin den relativen Effekt von vier Faktoren einschätzen, von denen angenommen wird, dass sie eine Toleranz der Bienen gegenüber den Milben bewirken. Achtundfünfzig Völker wurden in Beuten der Größe „Jumbo“ etabliert. Die Königinnen in diesen Völkern entstammten der Linienzucht von sieben verschiedenen Bienenzüchtern. Die Völker wurden mit jeweils 25 Milben infiziert. Um den Toleranzgrad der Völker gegenüber $V$. destructor zu bestimmen, wurde das Populationswachstum der Milben anhand von monatlichen Probennahmen von Arbeiterinnen und Brut über einen Zeitraum von 6 Monaten ermittelt. Zur Bestimmung phenotypischer und genetischer Variabilität wurden die Daten einer Varianzanalyse unterworfen. Zur Bestimmung des relativen Einflusses von vier Toleranzmechanismen wurden 16 Völker ausgewählt, dieses waren die acht Völker mit dem niedrigsten und die acht Völker mit dem höchsten Befallsgrad. Die untersuchten Mechanismen waren das Putzverhalten, das hygienische Verhalten, die Brutattraktivität und das vom Wirt verursachte Nichtreproduzieren der Milben. Jeder dieser Mechanismen wurde in einem Biotest erfasst und die Mittelwerte der acht hochbefallenen Völker mit denen der acht niedrigbefallenen anhand von $t$-Tests verglichen. Zusätzlich wurden die Daten mittels einer Varianzanalyse auf Unterschiede zwischen den ausgewählten Völkern hin untersucht. Für die Mechanismen, die zwischen den Gruppen oder den Völkern signifikante Unterschiede aufwiesen, wurden Regressionen und Korrelationen zwischen dem Endbefall der Völker und den Mittelwerten der erfassten Mechanismen berechnet. Zwischen den Völkern gab es signifikante Unterschiede im Befallsgrad der Bienen, aber es wurden keine signifikanten Unterschiede im Befallsgrad der Arbeiterinnenbrut gefunden (Abb. 2, 3). Zwischen Bienenlinien und zwischen Völkern innerhalb der Bienenlinien bestanden signifikante Unterschiede im Befall der Bienenarbeiterinnen (Abb. 1), die genetische und phänotypische Einflüsse belegen (Tab. I). Bei den untersuchten Mechanismen bestanden signifikante Unterschiede zwischen Bienenlinien 
und Völkern bezüglich des Putzverhaltens (Tab. II). Signifikante negative Korrelationen bestanden zwischen dem Endbefall der Völker und der Anzahl wiedergefundener Milben (Tab. III, Abb. 4), und zwischen dem Endbefall der Völker und der Anzahl verletzter Milben (Tab. III, Abb. 5). Unterschiede des hygienischen Verhaltens bestanden zwischen Völkern, aber nicht zwischen den Bienenlinien. Weder Brutattraktivität noch der Einfluss der Brut auf die Reproduktion der Milben unterschied sich zwischen Völkern oder Bienenlinien. Diese Ergebnisse legen nahe, dass die in dieser Studie gefundene Toleranz der Völker gegenüber $V$. destructor zu der Fähigkeit der Bienen in Beziehung stand, die auf den Arbeiterinnen phoretische Milbenpopulation zu begrenzen, dies geschah offensichtlich durch das Putzverhalten. Die mit der Messung von Toleranzmechanismen zusammenhängenden Probleme und Folgerungen sowie zukünftige Untersuchungen werden diskutiert.

\section{Apis mellifera / Varroa destructor / Toleranz / Resistenzmechanismen / Mexico}

\section{REFERENCES}

Anderson D.L., Trueman J.W.H. (2000) Varroa jacobsoni (Acari: Varroidae) is more than one species, Exp. Appl. Acarol. 24, 165-189.

Bär E., Rosenkranz P. (1992) Spezifisches putzverhalten von honigbienen (Apis mellifera) unterschiedlicher rassen gegenüber Varroa-infizierten brützellen. (Specific grooming behaviour towards brood cells infested with Varroa jacobsoni of different honey bee races.), Ann. Univ. M. Curie-Skl. 47, 1-6.

Beetsma J., Boot W.J., Calis J. (1999) Invasion behaviour of Varroa jacobsoni Oud.: from bees into brood cells, Apidologie 30, 125-140.

Bienefeld K., Zautke F., Pronin D., Mazedd A. (1999) Recording the proportion of damaged Varroa jacobsoni Oud. in the debris of honey bee colonies (Apis mellifera), Apidologie 30, 249-256.

Boecking O. (1992) Removal behavior of Apis mellifera towards sealed brood cells infested with Varroa jacobsoni: Techniques, extent and efficacity, Apidologie 23, 371-373.

Boecking O., Drescher W. (1991) Response of Apis mellifera L. colonies to brood infested with Varroa jacobsoni O., Apidologie 22, 237-241.
Boecking O., Rath W., Drescher W. (1993) Grooming and removal behavior: strategies of Apis mellifera and Apis cerana bees against Varroa jacobsoni, Am. Bee J. 133, 117-119.

Boecking O., Spivak M. (1999) Behavioral defenses of honey bees against Varroa jacobsoni Oud., Apidologie 30, 141-158.

Büchler R. (1992) Test auf Varroatoleranz in Rahmen von Leistungsprüfungen (Test for Varroa-tolerance performance), Neue Bienen Zeitung 3, 162-167.

Büchler R. (1989) Attractivity and reproductive suitability for the Varroa-mite of bee brood from different origins, in: Proceedings of the Meeting of the Economic Community Experts Group. Udine, Italy, pp. 139-145.

Calatayud F., Verdu M.J. (1993) Hive debris counts in honeybee colonies - A method to estimate the size of small populations and rate of growth of the mite Varroa jacobsoni Oud. (Mesostigmata: Varroidae), Exp. Appl. Acarol. 17, 889-894.

Camazine S. (1986) Differential reproduction of the mite Varroa jacobsoni (Mesostigmata: Varroidae) on Africanized and European honey bees (Hymenoptera: Apidae), Ann. Entomol. Soc. Am. 79, 801-803.

De Guzman L., Rinderer T.E., Stelzer J.A. (1997) The evidence of the origin of Varroa jacobsoni Oud. in the Americas, Biochem. Gen. 35, 327-335.

De Jong D., Roma D.A., Gonçalves L.S. (1982) A comparative analysis of shaking solutions for the detection of Varroa jacobsoni on adult honey bees, Apidologie 13, 297-306.

Elzen P.J., Eischen F.A., Baxter J.R., Elzen G.W., Wilson W.T. (1999) Detection of resistance in US Varroa jacobsoni Oud. (Mesostigmata: Varroidae) to the acaricide fluvalinate, Apidologie 30, 13-17.

Engels W., Gonçalves L.S., Steiner J., Buriolla A.H., Cavichio-Issa M.R. (1986) Varroa-Befall von carnica-Volkern in Tropenklima (Varroa infestation growth in carnica bees in tropical climate), Apidologie 17, 203-216.

Falconer D.S. (1989) Introduction to quantitative genetics, Longman Scientific and Technical.

Faucon J.P., Flamiini C. (1990) Résidus de fluvalinate dans la cire et dans le miel (Residues of fluvalinate in honey and wax), Santé Abeille 118, 182-184.

Fries I., Aarhus A., Hansen H., Korpela S. (1991) Comparison of diagnostic methods for detection of low infestation levels of Varroa jacobsoni in honey bee (Apis mellifera) colonies, Exp. Appl. Acarol. 10, 279-287.

Guerra J.C., Gonçalves L.S., De Jong D. (2000) Africanized honey bees (Apis mellifera L.) are more efficient at removing worker brood artificially infested with the parasitic mite Varroa jacobsoni Oudemans than are Italian bees or Italian/Africanized hybrids, Genet. Mol. Biol. 23, 89-92. 
Guzmán-Novoa E. Correa A. (1996) Selección de abejas melíferas (Apis mellifera L.) resistentes al ácaro Varroa jacobsoni Oud. (Selection of honey bees resistant to the mite Varroa jacobsoni Oud.), Veterinaria Méx. 27, 149-158.

Guzmán-Novoa E., Sanchez A.A., Page R.E. Jr., Garcia P.T. (1996) Susceptibility of European and Africanized honeybees (Apis mellifera L.) and their hybrids to Varroa jacobsoni Oud., Apidologie 27, 93-103.

Guzmán-Novoa E., Vandame R., Arechavaleta M.E. (1999) Susceptibility of European and Africanized honey bees (Apis mellifera L.) to Varroa jacobsoni Oud. in Mexico, Apidologie 30, 173-182.

Harbo J.R., Hoopingarner R. (1997) Honey bees (Hymenoptera: Apidae) in the United States that express resistance to Varroa jacobsoni (Mesostigmata: Varroidae), J. Econ. Entomol. 90, 893-898.

Harbo J.R., Harris J.W. (1999) Selecting honey bees for resistance to Varroa jacobsoni, Apidologie 30 183-196.

Hillesheim E., Ritter W., Bassand D. (1996) First data on resistance mechanisms of Varroa jacobsoni (Oud.) against tau-fluvalinate, Exp. Appl. Acarol. 20, 283-296.

Koeniger N., Koeniger G., Wijayagunasekar N.H.P. (1981) Anpassung von Varroa Jacobsoni an ihren natürlichen wirt Apis cerana in Sri Lanka (Observations about the adaptation of Varroa Jacobsoni on its natural host Apis cerana in Sri Lanka), Apidologie 12, 37-40.

Krause B., Page R.E. (1995) Effect of Varroa jacobsoni on feral Apis mellifera in California, Environ. Entomol. 24, 1473-1480.

Kulincevic J.M., Rinderer T.E. (1986) Differential survival of honey bee colonies infested by Varroa jacobsoni and breeding for resistance, in: Proceedings of the XXX Int. APIMONDIA Congress, Nagoya, Japan. pp. 175-177.

Kulincevic J.M., Rinderer T.E. (1988) Breeding honey bees for resistance to Varroa jacobsoni: Analysis of population dynamics and structure of mites progeny, in: Needham G.R., Page R.E. Jr., Delfinado-Baker M., Bowman C.E. (Eds.), Africanized Honey Bees and Bee Mites, Ellis Horwood, Chichester, UK, pp. 360-369.

Kulincevic J.M., Rinderer T.E., Urosevic D.J. (1988) Seasonality and colony variation of reproducing and non-reproducing Varroa jacobsoni females in western honey bee (Apis mellifera) worker brood, Apidologie 19, 173-179.

Lobb N., Martin S. (1997) Mortality of Varroa jacobsoni Oudemans during or soon after the emergence of worker and drone honeybees Apis mellifera L., Apidologie 28, 367-374.

Lodesani M., Colombo M., Spreafico M. (1995) Ineffectiveness of Apistan ${ }^{\circledR}$ treatment against the mite Varroa jacobsoni Oud. in several districts of Lombardy (Italy), Apidologie 26, 67-72.
Lodesani M., Pellacani A., Bergomi S., Carpana E. Rabitti T., Lasagni P. (1992) Residue determination for some products used against Varroa infestation in bees, Apidologie 23, 257-272.

Lynch M., Walsh B. (1998) Genetics and analysis of quantitative traits, Sinauer Associates, Inc., Massachusetts, pp. 779-800.

Moosbeckhofer R. (1992) Beobachtungen zum auftreten beschädigter varroamilben im natürlichen totenfall bei völkern von Apis mellifera carnica, Apidologie 23, 523-531.

Moosbeckhofer R., Fabsicz M., Kohlich A. (1988) Untersuchungen über die abhängigkeit der nachkommensrate von Varroa jacobsoni von befallsgrad der bienenvölkern, Apidologie 19, 181-207.

Moretto G., Mello L.J. (2000) Resistance of Africanized bees (Apis mellifera L.) as a cause of mortality of the mite Varroa jacobsoni Oud. in Brazil, Am. Bee J. 140, 895-897.

Moretto G., Gonçalves L.S., De Jong D., Bishuette M.Z. (1991) The effects of climate and bee race on Varroa jacobsoni Oud. infestations in Brazil, Apidologie 22, 197-203.

Moretto G., Gonçalves L.S., De Jong D. (1993) Heredability of africanized and european honey bee defensive behavior against the mite Varroa jacobsoni, Braz. J. Gen. 16, 71-77.

Morse R.A., Miska D., Robinson G.E. (1991) Varroa resistance in US honeybees, Am. Bee J. 131, 433-434.

Newton D.C., Ostasiewski N.J. (1986) A simplified bioassay for behavioral resistance to american foulbrood in honey bees (Apis mellifera L.), Am. Bee J. 126, 278-281.

Peng Y.S., Fang Y., Xu S., Ge L. (1987a) The resistance mechanisms of the Asian honey bee, Apis cerana Fabr., to an ectoparasitic mite, Varroa jacobsoni Oudemans, J. Invert. Pathol. 49, 54-60.

Peng Y.S., Fang Y., Xu S., Ge L., Nasr M.E. (1987b) Response of foster Asian honey bee (Apis cerana Fabr.) colonies to the brood of European honey bee (Apis mellifera L.) infested with the parasitic mite, Varroa jacobsoni Oudemans, J. Invertebr. Pathol. 49, 259-264.

Rath W., Drescher W. (1990) Response of Apis cerana Fabr. colonies towards brood infested with Varroa jacobsoni Oud. and infestation rate of colonies in Thailand, Apidologie 21, 311-321.

Ritter W., De Jong D. (1984) Reproduction of Varroa jacobsoni O. in Europe, the Middle East and tropical South America, Z. Angew. Entomol. 98, 55-57.

Ron M., Rosenthal C. (1987) Genetic differences in the resistance to varroasis of bees in Israel, in: Proceedings of the XXXI Int. APIMONDIA Congress, Warsaw, Poland, pp. 263-265.

Rosenkranz P. (1999) Honey bee (Apis mellifera) tolerance to Varroa jacobsoni Oud. in South America, Apidologie 30, 159-172. 
Rosenkranz P., Engels W. (1994) Infertility of Varroa jacobsoni females after invasion into Apis mellifera worker brood as a tolerance factor against varroasis, Apidologie 25, 402-411.

Rosenkranz P., Fries I., Boecking O., Stürmer M. (1997) Damaged Varroa mites in the debris of honey bee (Apis mellifera L.) colonies with and without hatching brood, Apidologie 28, 427-437.

Rothenbuhler W.C. (1964) Behaviour genetics of nes cleaning in honey bees: I. Responses of four inbred lines to disease-killed brood, Anim. Behav. 12, 578-583.

Ruttner F., Hänel H. (1992) Active defense against Varroa mites in a carniolan strain of honey bee (Apis mellifera carnica Pollmann), Apidologie 23, 173-187.

Slabezki Y., Gal H., Lensky Y. (1991) The effect of fluvalinate application in bee colonies on population levels of Varroa jacobsoni and honey bees (Apis mellifera L.) and on residues in honey and wax, Bee Sci. 1, 189-195.

Snedecor G., Cochran W. (1991) Statistical methods, 8th ed., Iowa State University, Iowa.
Spivak M. (1996) Honey bee hygienic behavior and defense against Varroa jacobsoni, Apidologie 27, 245-260.

Spivak M., Reuter G.S. (1998) Performance of hygienic colonies in a commercial apiary, Apidologie 29, 285-296.

Szabo T.I., Walker C.R.T. (1995) Damages to dead Varroa jacobsoni caused by the larvae of Galleria mellonella, Am. Bee J. 135, 421-422.

Van Vleck L.D. (1993) Selection index and introduction to mixed model methods, CRC Press.

Vandame R., Colin M.E., Otero-Colina G. (1997) Africanized honey bees tolerance to Varroa in Mexico: mite infertility is not the main tolerance factor, XXXVth Int. APIMONDIA Congress, Antwerp, Belgium.

Wallner A. (1990) Beobachtungen naturlicher Varroaabwehrreaktionen in meinen bienñenvolkern (Observations of honey bee natural Varroa-defensive reactions), Imkerfreund 9, 4-5.

Wallner K. (1999) Varroacides and their residues in bee products, Apidologie 30, 235-248. 